SUST AINABLE FORESTRY

COLLECTION 71-72, 2015
ODRŽIVO ŠUMARSTVO

ZBORNIK RADOVA 71-72, 2015

UDK $630 * 232.425 .1=111$

Original scientific paper

\title{
EFFECT OF FERTILIZERS ON CONCENTRATION OF PHOTOSYNTHETIC PIGMENTS IN JUVENILE SEEDLINGS OF EASTERN BLACK WALNUT (Juglans nigra L.)
}

\author{
Vladan POPOVIĆ ${ }^{1}$, Tatjana ĆIRKOVIĆ-MITROVIĆ, Ljubinko RAKONJAC, \\ Aleksandar LUČIĆ
}

\begin{abstract}
The paper presents the results of the effect of different fertilizers on concentration of photosynthetic pigments in leaves of juvenile seedlings of eastern black walnut (Juglans nigra L.). The seedlings were produced in 2014 in the seedling nursery of Institute of forestry in Belgrade. The trial was set up in a random block system with three types of fertilizers and a control in three replications. Three types of pigments have been examined: chlorophyll $\boldsymbol{a}$, chlorophyll $\boldsymbol{b}$ and carotenoids. The leaf sampling was carried out in the beginning of June 2014. The highest concentration of photosynthetic pigments was found in the leaves of seedlings treated with the preparation Osmocote ${ }^{\circledR}$ Exact Standard 5$6 \mathrm{M}$ and the lowest in the seedlings which were not treated. The highest mean value had chlorophyll a $(0.522 \mathrm{mg} / \mathrm{g})$ in treatment with Osmocote ${ }^{\circledR}$ Exact Standard 5-6 $M$ and the lowest mean value had chlorophyll $\boldsymbol{b}(0.213 \mathrm{mg} / \mathrm{g})$ in the control sample. The results showed that the concentration of photosynthetic pigments in leaves of eastern black walnut juvenile seedlings varied depending on the fertilizer that was applied. Based on the obtained results it can be concluded that the proper fertilizer can increase the concentration of photosynthetic pigments in leaves and therefore the intensity of photosynthesis which contributes to increasing the biomass production.
\end{abstract}

Key words: eastern black walnut, fertilizer, photosynthetic pigments.

\footnotetext{
${ }^{1}$ Institut of Forestry, Kneza Viseslava 3, Belgrade, Serbia. E-mail: vladanpop79@gmail.com

* Acknowledgement: The research is financed by the Ministry of Science and Technological Development of the Republic of Serbia, Project TR 31070 "The development of technological procedures in forestry with a view to an optimum forest cover realisation" (2011-2015).
} 


\title{
УТИЦАЈ ПРЕПАРАТА ИСХРАНЕ НА САДРЖАЈ \\ ФОТОСИНТЕТИЧКИХ ПИГМЕНАТА ЈУВЕНИЛНИХ САДНИЦА ЦРНОГ ОРАХА (Juglans nigra L.)
}

\begin{abstract}
Извод: У раду су приказани резултати утицаја различитих препарата исхране на садржај фотосинтетичких пигмената у листовима јувенилних садница ирног ораха (Juglans nigra L.). Саднице uрног ораха су произведене у расаднику Института за иумарство у Београду у 2014. години. Оглед је постављен по случајном блок систему са три варијанте прихране и контролом у три понављања. Од фотосинтетичких пигмента истраживани су: хлорофил а, хлорофил б и каротеноиди. Узории листова за мерење садржаја фотосинтетичких пигмената узети су у првој половини јула 2014. године. Највећи садржај фотосинтетичких пигмената утврђен је у листовима садница које су третиране препаратом Osmocote ${ }^{\circledR}$ Exact Standard 5-6 M, а најмањи код садница које нису третиране. Највећу просечну вредност имао је хлорофил а $(0,522 \mathrm{mg} / \mathrm{g})$ у третману Osтосоте® Exact Standard 5-6 M, а најмаюу хлорофил б (0,213 mg/g) у контролном узорку. Добијени резултати показују да се садржај фотосинтетичких пигмената у листовима садница ирног ораха мена у зависности од коришћеног препарата исхрана. На основу добијених резултата може се констатовати да се правилном исхраном биљака може повећати садржај фотосинтетичких пигмената у листу, а тиме и интензитет фотосинтезе, ито доприноси повећању продукиије биомасе.
\end{abstract}

Кључне речи: црни орах, препарат исхране, фотосинтетички пигменти.

\section{INTRODUCTION}

The role of photosynthetic pigments in plant organism is reflected in the absorption of light necessary for the process of photosynthesis. Chlorophylls are the primary photosynthetic pigments. They reflect green part of the spectrum of visible light, while carotenoids reflect yellow, orange or red part of the spectrum. The ability to absorb certain wavelengths of light is more important for the process of photosynthesis than the ability of reflection of the part of the light (Popovic et al., 2015). Due to different size and shape as well as different concentration of pigments, the leaves have different ability to absorb visible light and to transform it into energy of chemical bonds (Čivić et al., 2005). The use of various nutrition preparations can significantly influence the concentration of photosynthetic pigments and thus on photosynthesis as a whole (Janmohammadi et al., 2012).

Determination of concentration of photosynthetic pigments in leaves is justified having in mind that the intensity of photosynthesis largely depends on that. In this paper was researched the effect of three different nutrition preparations on concentration of photosynthetic pigments in leaves of juvenile, one-year-old seedlings of eastern black walnut (Juglans nigra L.).

\section{MATERIAL AND METHOD}

The seed of eastern black walnut collected in 2013 in micro-population in Arboretum of Faculty of forestry in Belgrade was used for trial set up. Due to 
embryo dormancy the walnut seed was moist stratified from November 2013 until end of March 2014 (at the temperature 3-5 ${ }^{\circ} \mathrm{C}$ ). The sowing was performed in rows at a depth of $5 \mathrm{~cm}$ in April 2014 in the seedling nursery of the Institute of forestry in Belgrade. The seed was planted in TrefTPS fine brown substrate. The trial was set up in three replications. Except the control block which was not treated with nutrition preparations, three blocks of trial fields were treated with three types of fertilizers: the controlled release fertilizer Osmocote ${ }^{\circledR}$ Exact Standard 5-6 M, the microbiological preparation Bactofil ${ }^{\circledR}$ B 10 and the complex NPK mineral fertilizer Florin 2, the dosage is recommended by the manufacturers (ĆirkovićMitrović, T., 2014).

Leaf sampling of eastern black walnut seedlings was conducted at 10th July 2014. The concentration of photosynthetic pigments was determined on the same day in the laboratory of the Institute of forestry. A sample of $1 \mathrm{~g}$ was homogenized using a mortar and pestle. For better homogenization of the sample 2 $\mathrm{g}$ of quartz sand was added in the mortar before mechanical grinding. The paste was for 3 minutes treated with $15 \mathrm{ml}$ of $80 \%$ acetone. To this mixture was added 1 $\mathrm{mg}$ of $\mathrm{MgCO}_{3}$ in order to prevent acidification of the solution. The resulting green solution was applied by a small glass rod on a glass filter and using a water spray vacuum pump it was filtered into the vacuum test tube. The resulting filtrate was the pigment extract which is transferred from the test tube to the regular $25 \mathrm{ml}$ vessel and supplemented with $80 \%$ acetone to the line. To perform reading in a spectrophotometer the obtained extract has to be diluted. $1 \mathrm{ml}$ of the obtained extract was taken by pipette and into that was added $9 \mathrm{ml}$ of acetone and then it was transferred to the test tube. Thus prepared extract was poured into the cuvette and read on the spectrophotometer, the absorption was at the wavelengths 662,644 and $440 \mathrm{~nm}$. The formula of Holm and Wetsttein was applied to calculate the concentration of the pigment in the extract in $\mathrm{mg} / \mathrm{dm}^{3}$.

Preparation and reading on the spectrophotometer as well as calculation was performed using standard methods (Oljača, R., Srdić, M., 2005).

\section{RESULTS AND DISCUSSION}

Table 1 presents the concentration of photosynthetic pigments in eastern black walnut leaves depending on the applied nutrition preparation. Based on these results it can be concluded that the concentration of photosynthetic pigments in leaves of seedlings treated with nutrition preparations was increased compared to control seedlings.

The greatest concentration of chlorophyll a in the amount of $0.522 \mathrm{mg} / \mathrm{g}$ was measured in the seedlings treated with Osmocote and the lowest in the control seedlings in the amount of $0.346 \mathrm{mg} / \mathrm{g}$. The concentration of chlorophyll $\mathbf{b}$ was in the range of 0.213 to $0.349 \mathrm{mg} / \mathrm{g}$. The highest concentration was measured in the seedlings treated with Osmocote and the lowest in the seedlings that were not treated with fertilizers. The concentration of carotenoids was ranging from 0.227 $\mathrm{mg} / \mathrm{g}$ which was measured in the seedlings that were not treated with fertilizers to $0.400 \mathrm{mg} / \mathrm{g}$ as measured in the seedlings treated with Osmocote (Table 1, Graphs 1, $2,3)$. 
Table 1. Concentration of photosynthetic pigments in eastern black walnut leaves depending on nutrition preparation type

\begin{tabular}{|c|c|c|c|}
\hline Fertilizer & Chlorophyll a mg/g & Chlorophyll b mg/g & Carotenoids mg/g \\
\hline Control & 0.346 & 0.213 & 0.227 \\
\hline Osmocote & 0.522 & 0.349 & 0.400 \\
\hline Bactofil & 0.374 & 0.288 & 0.386 \\
\hline Florin & 0.370 & 0.285 & 0.341 \\
\hline
\end{tabular}

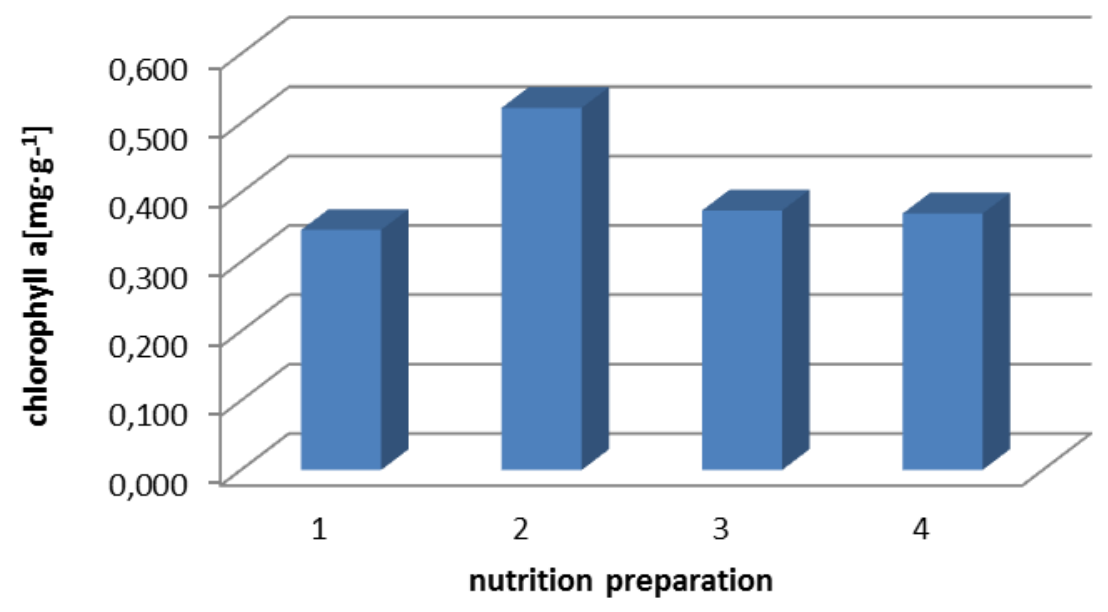

Note: 1-Control, 2- Osmocote, 3- Bactofil, 4- Florin

Graph 1.Concentration of chlorophyll a in eastern black walnut leaves depending on nutrition preparation type

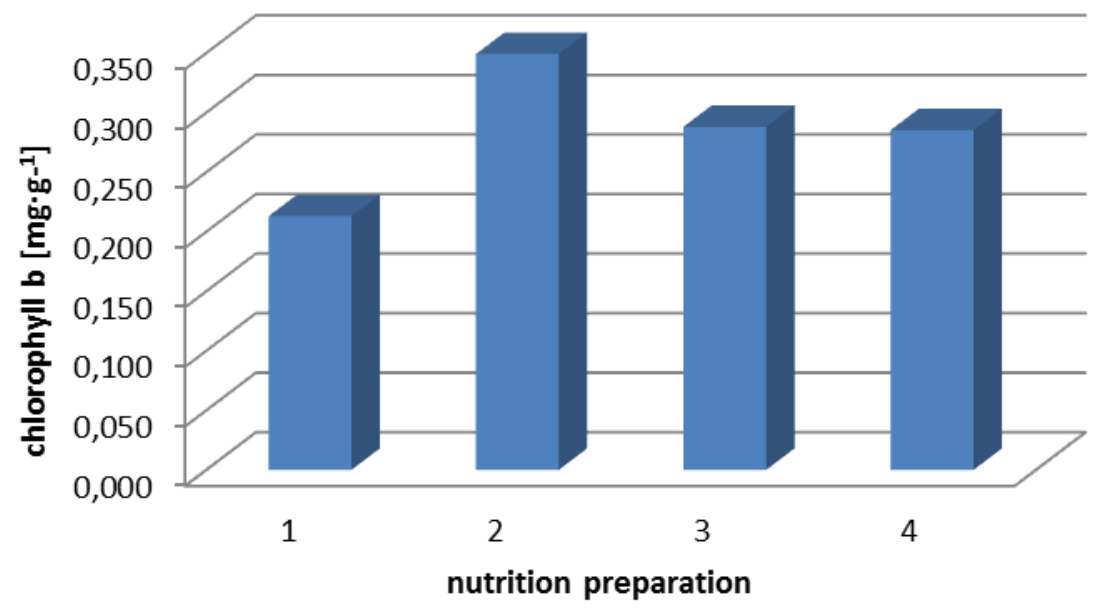

Note: 1-Control, 2- Osmocote, 3- Bactofil, 4- Florin

Graph 2. Concentration of chlorophyll $\boldsymbol{b}$ in eastern black walnut leaves depending on nutrition preparation type 


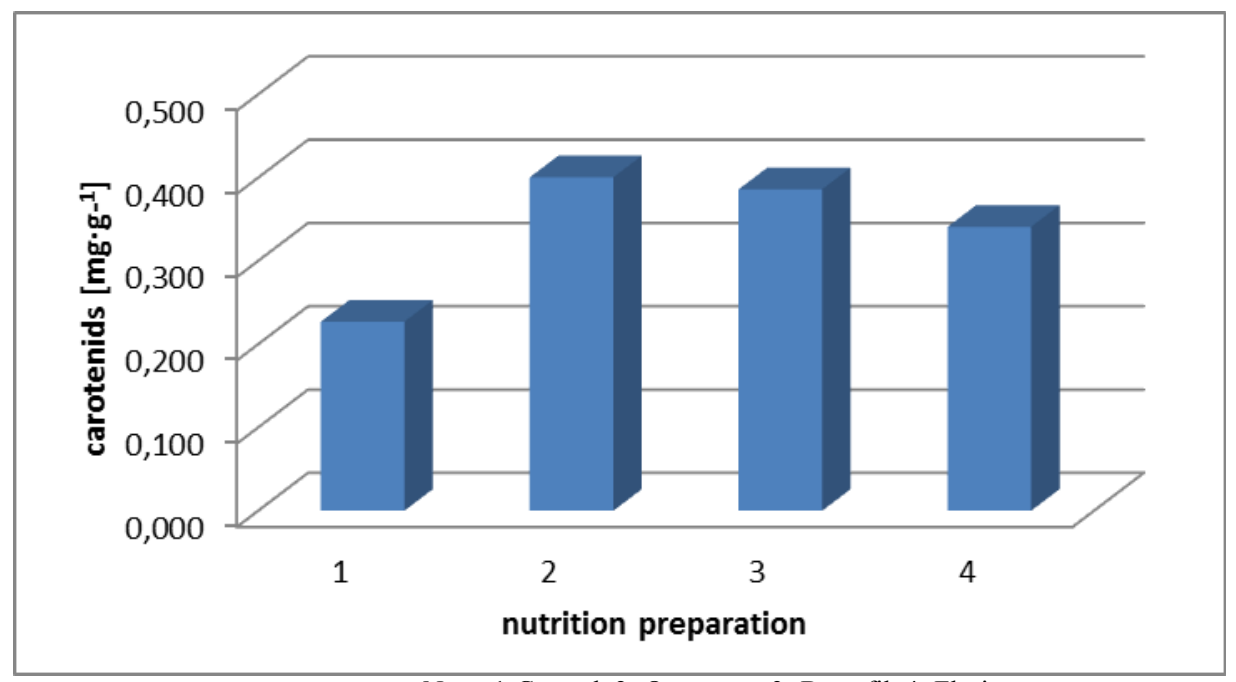

Note: 1-Control, 2- Osmocote, 3- Bactofil, 4- Florin

Graph 3. Concentration of carotenoids in eastern black walnut leaves depending on nutrition preparation type

The results showed that the addition of the nutrition preparations in the substrate in the first year of eastern black walnut seedlings growth had positive effect on the concentration of photosynthetic pigments in the leaves of these plants. The highest concentration of photosynthetic pigments was determined in juvenile eastern black walnut seedlings treated with Osmocote ${ }^{\circledR}$ Exact Standard 5-6 M. Positive effect of this nutrition preparation reflected also on development and morphometric characteristics of seedlings. Other applied nutrition preparations also positively affected concentration of photosynthetic pigments in the seedlings' leaves but the measured values are slightly lower. Untreated seedlings have the lowest concentration of measured photosynthetic pigments and compared to treated seedlings they lagged behind development.

A foliar concentration of the main photosynthetic pigments chlorophyll a and $\mathbf{b}$ is considered to be a bio-indicator of the total primary production of biomass (Gitelson, A., Merzlyak, M. N., 1994). The research results of some authors also showed that the fertilization has a positive effect on concentration of photosynthetic pigments and quality of plants (Bravdo et al., 1993, Tojnko et al., 2001, Nellsen et al., 2003, Čivić et al., 2005). Nutrition has the positive effect on the concentration of photosynthetic pigments in walnut seedlings (Popović et al., 2015). Also, the nutrition preparations have the positive effect on the quality and morphometric characteristics of one-year-old seedlings of eastern black walnut (Ćirković-Mitrović, T., 2014a). The positive effect of microbiological preparations on the quality, morphometric characteristics and yield of plants was also determined in researches of authors Kristek, C. et al. (2010), Dolijanović, Ž. et al. (2014), etc.

\section{CONCLUSIONS}


Based on the conducted researches it can be concluded that the applying of nutrition preparations has the positive effect on concentration of photosynthetic pigments in leaves of eastern black walnut seedlings and on their growth and development. Usage of mineral fertilizer Osmocote ${ }^{\circledR}$ Exact Standard 5-6 M which gave the best results in terms of increasing the concentration of photosynthetic pigments can be recommended for a regular nursery production because this is slow release fertilizer so the fertilization is achieved throughout the vegetation season. When using fertilizers it has to be taken into account dosage because excessive intake of mineral substances which is characteristic of conventional production can adversely affect the general condition and development of the plants.

A simple, quick and inexpensive way of using this type of fertilizer by adding directly to substrate during its preparation, as well as controlled decomposition which look after the needs of the plants and the relatively long duration of effect justify its use in the mass production of high quality planting material for different purposes.

\section{LITERATURE}

Čivić, H., Šaćiragić, B., Drkenda, P., Kurtović, M., Hanić E. (2003): The scaling of fertilizer in the system of Integrated Fruit Production (IPV). First Symposium of Agriculture, Veterinary and Forestry, Neum (In original: Čivić, H., Šaćiragić, B., Drkenda, P., Kurtović, M., Hanić E. (2003.): Normiranje gnojiva u sistemu integralne proizvodnje voća (IPV). Prvi simpozij poljoprivrede, veterinarstva i šumarstva, Neum).

Ćirković-Mitrović, T. (2014): Influence of different nutrition preparations on morphoanatomical characteristics of wild fruit seedlings, PhD Thesis, Faculty of Forestry, University of Belgrade, 0-315.

Ćirković-Mitrović, T. (2014a): The effect of application of microbiological preparation on height growth dynamics of one-year old seedling of black walnut (Juglansnigra L.). Sustainable Forestry Vol. 69-70, Institute of Forestry, p. 47-54.

Dolijanović, Ž, Oljača, S., Kovačević, D, Šeremešić, S., Jovović, Z. (2014): The effect of growing locality, microbiological fertilizers and soil improvement preparations on productivity of buckwheat (Fagopyrum esculentum Moench). Journal of Agricultural Sciences Vol. 59, No. 1 (25-34). (In original: Dolijanović, Ž, Oljača, S., Kovačević, D, Šeremešić, S., Jovović, Z. (2014). Uticaj lokaliteta gajenja, mikrobioloških đubriva $i$ oplemenjivača zemljišta na produktivnost heljde (Fagopyrum esculentum Moench). Journal of Agricultural Sciences Vol. 59, No. 1 (25-34)).

Gitelson, A., Merzlyak, M. N. (1994): Spectral reflectance changes associated with autumn senescence of Aesculushippocastanum L. and Acer platanoides L. leaves. Spectral features and relation to chlorophyll estimation. Journal of Plant Physiology, 143(3), pp. 286-292.

Janmohammadi, M., Javanmard, A., Sabaghnia, N. (2012): Influences of micro-nutrients (zinc and iron) and bio-fertilizer on yield and yield components of chickpea (Cicer arietinum L.) cultivars. Agriculture \& Forestry, Vol. 57. (11) Issue 3: 53-66, 2012, Podgorica, Crna Gora (Montenegro). 
Kristek, S., Kristek, A., Pintar, I., Tetkiš, J., Kocevski, D. (2010): Effect of microbiological preparation BactoFil on yield and quality of sugar beet, 45th Croatian \& 5th International Symposium on Agriculture, (90-94). (In original: Kristek, S., Kristek, A., Pintar, I., Tetkiš, J., Kocevski, D. (2010): Utjecaj primjene mikrobiološkog preparata BactoFil-a na prinos $i$ kvalitetu šećerne repe, 45th Croatian \& 5th International Symposium on Agriculture, (9094)).

Oljača, R., Srdić, M. (2005): Plant Physiology, Practicum, University in Banja Luka, Faculty of forestry, Banja Luka. (In original: Oljača, R., Srdić, M. (2005): Fiziologija biljaka, praktikum, Univerzitet u Banjoj Luci Šumarski fakultet, Banja Luka).

Popovic, V., Cirkovic-Mitrovic, T., Lucic, A., Rakonjac, Lj. (2015): Effect of fertilizers on concentration of photosynthetic pigments in leaves of one-year-old seedlings of walnut (Juglans regia L.). Agriculture and Forestry, 61(4): 243-247.

Tojnko, S., Čmelik, Z., Zadravec, P. ( 2001.): Influence of fertigation with nitrogen on leaf mineral composition and cropping of Jonagold and Golden Delicious apple trees. ActaHorticulturae.

\title{
EFFECT OF FERTILIZERS ON CONCENTRATION OF PHOTOSYNTHETIC PIGMENTS IN JUVENILE SEEDLINGS OF EASTERN BLACK WALNUT (Juglans nigra L.)
}

\author{
Vladan POPOVIĆ, Tatjana ĆIRKOVIĆ-MITROVIĆ, Ljubinko RAKONJAC, Aleksandar \\ LUČIĆ
}

\section{Summary}

The role of photosynthetic pigments in plant organism is reflected in the absorption of light necessary for the process of photosynthesis. Chlorophylls as the primary photosynthetic pigments reflect green part of the spectrum of visible light, while carotenoids reflect yellow, orange or red part of the light spectrum.

This paper researched the effect of different nutrition preparations on concentration of photosynthetic pigments in leaves of juvenile seedlings of eastern black walnut (Juglans nigra L.). The following photosynthetic pigments were examined: chlorophyll a, chlorophyll $\mathbf{b}$ and carotenoids.

The results showed that the addition of the nutrition preparations in the substrate in the first year of eastern black walnut seedlings growth had positive effect on the concentration of photosynthetic pigments in the leaves of these plants. The highest concentration of photosynthetic pigments was determined in juvenile eastern black walnut seedlings treated with Osmocote ${ }^{\circledR}$ Exact Standard 5-6 M. Positive effect of this nutrition preparation reflected also on development and morphometric characteristics of seedlings. Other applied nutrition preparations also positively affected concentration of photosynthetic pigments in the seedlings' leaves but the measured values are slightly lower. Untreated seedlings have the lowest concentration of measured photosynthetic pigments and compared to treated seedlings they lagged behind development.

Based on the conducted researches it can be concluded that the proper nutrition can increase the concentration of photosynthetic pigments in leaves of eastern black walnut seedlings and also the intensity of photosynthesis and thus their growth and development. 


\title{
УТИЦАЈ ПРЕПАРАТА ИСХТРАНЕ НА САДРЖАЈ ФОТОСИНТЕТИЧКИХ ПИГМЕНАТА ЈУВЕНИЛНИХ САДНИЦА ЦРНОГ ОРАХА (Juglans nigra L.)
}

\author{
Владан ПОПОВИЋ, Татјана ЋИРКОВИЋ-МИТРОВИЋ, Љубинко РАКОЊАЦ, \\ Александар ЛУЧИЋ
}

\section{Резиме}

У биљном организму фотосинтетички пигменти су задужени за апсорпцију светлости неопходне за одвијање процеса фотосинтезе. Хлорофили као примарни фотосинтетички пигменти рефлектују зелени део спектра видљиве светлости, док каротеноиди рефлектују жути, наранџасти или црвени део спектра светлости.

У раду је истраживан утицај различитих препарата исхране на садржај фотосинтетичких пигмената у листовима јувенилних садница црног ораха (Juglans nigra L.). Од фотосинтетичких пигмента истраживани су: хлорофил а, хлорофил $б$ и каротеноиди.

Резултати истраживања показали су да додавање препарата исхране у супстрат у првој години раста садница црног ораха позитивно утиче на садржај фотосинтетичких пигмената у листовима ових биљака. Највећи садржај фотосинтетичких пигмената утврђен је код јувенилних садница црног ораха које су третиране препаратом Osmocote ${ }^{\circledR}$ Exact Standard 5-6 М. Позитиван утицај овог препарата исхране одразио се на развој и морфометријске карактеристике садница. Остали примењени препарати исхране такође позитивно утичу на садржај фотосинтетичких пигмената у листовима садница, стим да су измерене вредности нешто ниже. Саднице које нису прихрањиване имају најмањи садржај мерених фотосинтетичких пигмената, а у односу на прихрањиване саднице заостају у порасту.

На основу обављених истраживања може се констатовати да се правилном исхраном биљака може повећати садржај фотосинтетичких пигмената у листу садница црног ораха, односно интензитет фотосинтезе, а тиме и њихов раст и развој. 